\title{
Adenovirus Type 5 Antibody
}

National Cancer Institute

\section{Source}

National Cancer Institute. Adenovirus Type 5 Antibody. NCI Thesaurus. Code C120480.

An antibody produced in response to exposure to adenovirus serotype 5 . 